\title{
THE STATUS OF THE BLACK-FOOTED FERRET IN CANADA
}

RICHARD I. LAING, Box 1171, Lethbridge, Alberta, T1] 4A4, and GEOFFREY L. HOLROYD, Canadian Wildlife Service, 2nd Floor, 4999-98 Avenue, Edmonton, Alberta. T6B $2 \times 3$

Black-footed Ferrets (Mustela nigripes) once ranged throughout southern Saskatchewan but reportedly have disappeared from the Canadian prairie landscape. Recent sightings and previously unreported specimens of Blackfooted Ferrets suggest that the species still may exist on large tracts of native grasslands. The purpose of this paper is to evaluate recent sightings of Blackfooted Ferrets and to assess the possibility of the continuing existence of this species in Canada.

At present, the Black-footed Ferret is one of the most endangered species in North America and is listed as endangered in the United States. ${ }^{3}$ Historically, Black-footed Ferrets occurred throughout the Temperate Grassland Biome from Texas to Saskatchewan. Their range corresponded closely with the historical range of three species of prairie dogs (Cynomys spp.) ${ }^{1}$, except in Canada, where their range extended beyond that of prairie dogs (Fig. 1). When associated with prairie dogs, Black-footed Ferrets prey on them and use their burrows for shelter and nesting. ${ }^{10}$ To our knowledge, Black-footed Ferrets never have been studied outside the range of prairie dogs.

Between 1900 and 1937 Black-footed Ferrets were collected throughout much of southern Saskatchewan (Fig. 1). ${ }^{2}$ They also may have occurred in Alberta and Manitoba, but this is not well documented. The museum record (A1, Fig. 1) is a Black-footed Ferret collected in 1901 near Gleichen, Alberta. There are no reports of ferrets being collected in Manitoba. The last previously reported Canadian specimen was collected in 1937 near Climax, Saskatchewan.

\section{Historic Specimens and Records}

Two new specimens have been reported to us. A mounted Black-footed Ferret located in Belmore's Altamont Museum in Coutts, Alberta (J.R. Butler and B. Schultz, pers. comm.) was purchased in approximately 1960 but there is no record of its collection location or date. Mr. Schultz said ferrets were common in the area near Coutts about 1950. Another specimen in the Shaunavon Museum, Saskatchewan, was killed in 1965 in a haystack of George Hayes, 2 km from Val Marie (L. Perrault, pers. comm.). Although there are no data attached to the specimen it was mounted on a distinctive door panel by a church sister in the presence of Mrs. Perrault's brother (L. Perrault, pers. comm.). Mrs. Perrault also reported that Joe Laturnus trapped 18 Black-footed Ferrets near Val Marie in the winter of 1937-1938 and shipped them to Winnipeg where there was no market, so they were returned. That same winter Albert Archer trapped one ferret at Orkney, $30 \mathrm{~km}$ southwest of Val Marie.

\section{Searches}

There have been two systematic searches for Black-footed Ferrets in Canada. ${ }^{78}$ The first, conducted from 1975 to 1976 , involved more than $200 \mathrm{~h}$ searching for ferrets and field signs in prairie dog colonies in southern Sas: katchewan. 8 Field signs suggesting the presence of ferrets include: burrow plugging, characteristic diggings, tracks, scats and ferret remains. One prairie dog colony was spotlighted after $30-40$ plugged burrows were discovered. ${ }^{8}$ Prairie dogs are thought to plug burrows to defend themselves from predators that enter burrows (e.g., ferrets and weasels, Mustela spp. $)^{5}$, and plugged burrows 


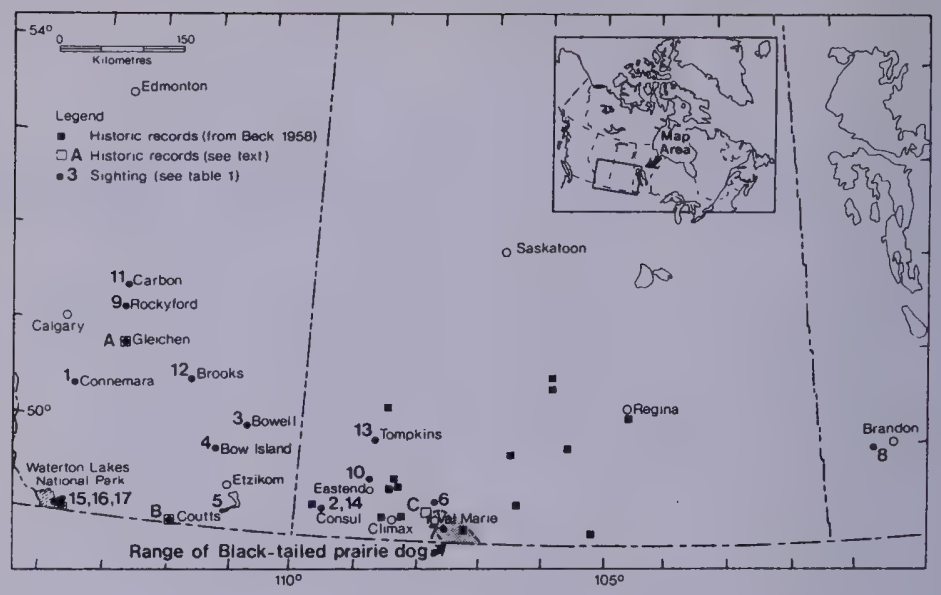

Figure 1. Distribution of Black-footed Ferret and Black-tailed Prairie Dog in Canada.

were the only possible field signs of ferrets observed. ${ }^{8}$ The second search was made in 1985 by $R$. Laing in prairie dog colonies and adjacent lands in southern Saskatchewan. The search was concentrated in evening hours with a spotlight. Four of 14 colonies were surveyed, but only two colonies were searched for more than three evenings. Conclusive evidence of Black-footed Ferrets in Saskatchewan was not found, but neither search was conducted in the winter, the most effective time to locate ferret signs. ${ }^{78}$ Furthermore, searches were concentrated in only a small portion of the historical range of Black-footed Ferrets in Canada.

\section{Collections and Sightings}

We contacted 10 public institutions to obtain recently recorded sightings of Black-footed Ferrets. Since 1967, 16 putative sightings (nine in Alberta, six in Saskatchewan and one in Manitoba) were reported to a variety of agencies (Table 1). We communicated with all but two of the original observers and visited all but two of the sites.

In 1972, a carcass was found in southern Alberta (sighting 5). ${ }^{9}$ Although the specimen was not collected, the description suggested that it was a Black-footed Ferret. Within the group of sightings we report, the time length varies from a few seconds (sightings $1,3,6,10 \& 14$ ) to several minutes. On three occasions the observation period was from 5-30 minutes (sightings $2,4 \& 12$ ). All observations were of individual animals except sighting number 2 , in which $\mathrm{K}$. Broderick observed four or five young Black-footed Ferrets near Consul, Saskatchewan, for approximately 30 minutes. He returned 2-3 months later with another person and again observed the ferret group. This is our only sight record of a litter. 
Two observations were by individuals familiar with other species of ferrets. Sighting 12 was reported by an Austrian researcher who is familiar with Siberian Ferret (Mustela eversmanni), a species nearly identical to the Black-footed Ferret. This observation was for 5-10 minutes at a distance of 10 to $15 \mathrm{~m}$, using $10 \times 40$ binoculars. L. Murray (sighting 13) believes the animal he saw was a Blackfooted Ferret, based on recognized body features similar to those of a domestic ferret he once owned.

We found the characteristic trenched diggings of ferrets at the locations of sightings 8,11 and 12 . We noted a high density of Richardson's Ground Squirrels near the areas where sightings 8,10 , 11 \& 12 were recorded, and Columbian Ground Squirrels at sites 15, $16 \& 17$. We propose that the density of ground squirrels at these sites could sustain a population of Black-footed Ferrets.

\section{Discussion}

All of the sight records in Table 1 suggest that the observers saw a ferretlike animal. Black-footed Ferrets have been confused with Long-tailed Weasels, European ferrets and domestic ferrets. If a face mask or black feet and legs are observed (as in sightings 2, 3, $4,5,8,11,12,13,15,16 \& 17)$, then a Long-tailed Weasel is excluded. If a black-tipped tail is observed (as in sightings $5,10,12 \& 15)$, both European and domestic ferrets are excluded. The strongest indication of the presence of Black-footed Ferrets in southwestern Canada is the relatively recent find by Pinel (1973).

Sightings $2,4,15 \& 17$ are compelling because the observers reported seeing dark masks and dark legs, and record 2 suggests breeding of Black-footed Ferrets beyond prairie dog colonies. This supports our view that Black-footed Ferrets in Canada were representatives of a breeding population and not merely dispersing individuals from populations in the United States.

A close association between Blackfooted Ferrets and Black-tailed or White- tailed Prairie Dogs has been well documented by researchers in the United States. Only Black-tailed Prairie Dogs occur in Canada, in a small area in southern Saskatchewan. According to the historical range of the Black-footed Ferret based on museum records, it is apparent that Black-footed Ferrets lived in Canada in the absence of prairie dogs. Given our knowledge of the close dependence of Black-footed Ferrets on prairie dogs, it seems probable they also could have adapted to other species of ground squirrels.

Only one of the 17 Black-footed Ferret reports listed in Table 1 was near a prairie dog colony. Eight sightings were in areas where Richardson's Ground Squirrels were common. Most sightings were in mixed-grass prairie, the least disturbed portion of the Canadian prairie. Of the mixed-grass prairie vegetation type, it is estimated that 32 to 41 percent is still relatively undisturbed. ${ }^{411}$

\section{Conclusion}

We believe Black-footed Ferrets still exist in Canada in areas well beyond the range of Black-tailed Prairie Dogs. Their former range in Saskatchewan was extensive. ${ }^{2}$ Although many areas have been cultivated since the 1930s, large areas of native grasslands still remain and could provide suitable habitat for Black-footed Ferrets, particularly where there are high densities of ground squirrels.

\section{Acknowledgements}

We thank those people who provided us with Black-footed Ferret sightings and those who forwarded sighting records to us, namely: R. Ashton, K. Bauer, K. Broderick, J.R. Butler, F.G. Cooch, D. Goble, F. Goble, M. Killaby, D. Muir, L. Murray, E. Nadeau, A. Orsen, L. Pennault, R.H. Russell, R. Sainsbury, B.H. Schulz, F. Spitzenburger, J. Stelfox, N. Tripp, S. van Zyll de Jong, D. Westland, P. Wiebe, M. Wilson and the Calgary Field Naturalists. S. Popowich drafted Figure 1, and M.B. Fenton, H.W. Reynolds and J.P. Goossen provided critical comments on earlier drafts. 
${ }^{1}$ ANDERSON. E., S.C. FORREST, T.W. CLARK and L. RICHARDSON. 1986. Paleobiology, biogeography, and systematics of the blackfooted ferret. Great Bas. Nat. Memoirs No. 8., pp. 11-62.

${ }^{2}$ BECK, W.H. 1958. A guide to Saskatchewan's mammals. Spec. Pub. No. 1, Sask. Nat. Hist. Soc., pp. 19-20.

${ }^{3}$ CARR, Archie III. 1986. The black-footed ferret. Great Bas. Nat. Memoirs No 8., pp. 1-7.

${ }^{4}$ COUPLAND, R.T. 1987. Endangered prairie habitats: The mixed grass prairie. Pages 3542 in HOLROYD, G.L. et al. (editors). Proceedings of the workshop on endangered species in the prairie provinces. Prov. Mus. of Alberta, Occasional Paper No. 9.367 pp.

${ }^{5}$ HILLMAN, C.N. 1968. Life history and ecology of the black-footed ferret in the wild. Unpub. manuscript thesis. South Dakota State University, Brookings, South Dakota. $28 \mathrm{pp}$.

${ }^{6}$ LAING, R. 1986. The feasibility of reintroducing the black-footed ferret to the
Canadian prairie. Unpub. masters degree project. University of Calgary, Calgary, Alberta. $134 \mathrm{pp}$.

7 1987. The black-tailed prairie dog in Saskatchewan. Blue Jay 45:177-180.

${ }^{8}$ MILLSON, R. 1976. The black-footed ferret in the proposed Grasslands National Park. Unpub. masters degree project. University of Calgary, Calgary, Alberta. 107 pp.

${ }^{9}$ PINEL, H.W. 1973. A recent black-footed ferret record for southern Alberta. Blue Jay 31:9-10.

${ }^{10}$ SHEETS, R.G. 1970. Ecology of the blackfooted ferret and the black-tailed prairie dog. Unpub. manuscript thesis. South Dakota State University, Brookings, South Dakota. 44 pp.

${ }^{11}$ WALLIS, C. 1987. Critical, threatened and endangered habitats in Alberta. Pages 49-63 in HOLROYD, G.L. et al. (editors). Proceedings of the workshop on endangered species in the prairie provinces. Prov. Mus. of Alberta, Occasional Paper No. 9.367 pp.

Table 1. RECENT BLACK-FOOTED FERRET SIGHTINGS

No. Date

1) 1967

2) 1968

3)

4)

5)

$09 / 72$

3) $08 / 69$

$10 / 69$
Location

Connemara,

Alberta

$1.5 \mathrm{~km}$ north

Consul, Saskatchewan

$1 \mathrm{~km}$ east
Bowell,

Alberta

Bow Island, Alberta

Etzikom,

Alberta

West end of

Pakowki Lake

6)
Val Marie, Saskatchewan $20 \mathrm{~km}$ north
Observers

M. Skirrow

K. Broderick

N. Tripp

P. Wiebe

H. Pinel

E. Nadeau

\section{Description}

No Description, the animal was clearly observed as it ran across the highway, observed at $4: 30$ p.m.

Litter of four or five Black-footed Ferrets, saw a black face mask, observed twice, once by two observers

Golden brown, weasel size, dark mask

Oversized weasel, light body colour, dark mask and legs.

Found a dead, decayed Black-footed Ferret, stubby muzzle, long body, blacktipped tail, black feet and mask, not collected

No description, ran across Highway \#4 
7)

$08 / 75$

Val Marie, Saskatchewan $15 \mathrm{~km}$ southeast

8) $\quad 06 / 76$

9) 1976

10)

$06 / 79$

11)

$07 / 80$

12)

08/85

13)

1985

14) $10 / 86$

15)

$06 / 88$

16)
$08 / 88$

17)

08/88
Grand Valley, near Brandon, Manitoba

Rockyford, Alberta

Eastend, Saskatchewan $6.4 \mathrm{~km}$ north in Chimney

Coulee

Carbon, Alberta

Brooks, Alberta Tillebrook Provincial Park

Tompkins
Saskatchewan
$1 \mathrm{~km}$ south

Consul, Saskatchewan Nashlyn PFRA Community Pasture

Waterton
Lakes

Waterton

Lakes

National Park

Palmer Ranch near Waterton Park

L. Murray

R. Ashton

F. Goble

A. Orser
B. Goodhope No description

M. Wilson

R. Sainsbury

W. Preston

D. Westland

F. Spitzenburger

Tawny-brown body, black face mask and black feet, observed in daylight

Saw a Black-footed Ferret chasing a ground squirrel, no description

\section{Larger than nearby}

Richardson's Ground

Squirrels, face mask

Yellow pelage, black-

tipped tail, black face mask

Fawn colour, long body approximately $40 \mathrm{~cm}$, dark

Saw a ferret-like animal, believed to be a Black-footed

Very pale colour, larger than a Long-tailed Weasel, with a shorter black-tipped tail

$$
\text { no description }
$$

Saw a small, thin, beige weasel with black feet, legs and face mask. He reports seeing other ferrets during the summer of 1988

Saw a weasel-like animal, $30-45 \mathrm{~cm}$ long, which had a black face mask

Saw a long weasel-like animal with dark face markings, ears and feet 